\title{
Innovative capacity as a factor of the municipal healthcare system development
}

\author{
Angela Mottaeva ${ }^{1,2, *}$ and Alexander Zheltenkov ${ }^{2}$ \\ ${ }^{1}$ Moscow State University of Civil Engineering, 26, Yaroslavskoye Shosse, 129337, Moscow, Russia \\ ${ }^{2}$ Moscow regional state University, Radio str. 10, 129125, Moscow, Russia
}

\begin{abstract}
Assuming, that it is vitally important to introduce and apply newest technological approaches the author studies the opportunities to Increase in innovative capacity of the medical organizations. In article the structure of innovative capacity of the medical organization is considered, features of the increase in innovative capacity of the medical organizations are revealed, methods and approaches of the increase in innovative potential are systematized. Having studied the existing approaches and methods of assessment and increase in innovative capacity of the medical organizations, the author reveals the most effective ones for practical application and also offers some methodical and practical recommendations for the increase in innovative capacity of the medical organizations. That is pointed out, that in turn the increase in innovative capacity will allow the medical organizations to provide the Municipal Healthcare System as whole with sustainable development.
\end{abstract}

\section{Introduction}

Recently, the innovative capacity of the medical organizations, have become the major factor, allowing to get the competitive advantages, providing the accelerated development of enterprise structures on the basis of the effective use of material, labour, financial and information resources. However it should be noted that the existing mechanism of innovative potential management is characterized by the lack of regularity in causal communications and functional interactions among various medical organizations, participating in innovative process. This circumstance does not allow various levels of management to use available innovative potential effectively, to provide growth of innovative capacity of economic entities that negatively affects rates of economic growth. The main factor, interfering increase in innovative potential is insufficiency of the medical organizations own means, therefore the special is paid on the questions of search and development of new forms of financing of innovative process.

Practice of some countries demonstrates that one of the effective alternative versions of the solution of this problem is activity of funds of the venture capital. However, attempts of their creation in domestic economy on the basis of direct loan of foreign experience do not give the expected result. Thus the research of the mechanism of innovative potential

\footnotetext{
*Corresponding author: angela-1309.m@yandex.ru
} 
management, taking into account specific features of Russia is very relevant. The flexibility of reaction and the variety of methods and ways of influence of the specified mechanism, rational consumption of all the types of resources and intensive development of innovative processes can be reached only in case of adoption of the perspective and strategic decisions, aimed at the improvement of interaction among the separate medical organizations in innovative process [1-3].

There are institutional and organizational restrictions on realization of innovative capacity, gaps in technological and innovative development, in ensuring continuity of process of reproduction of innovations, in the medical organizations, and that reduces possibilities of formation of any uniform innovative space.

Methodological approaches to the assessment of innovative capacity of the medical organizations are developed by V. Akberdina, E. Amosenok, E. Aleksandrova, V. Bazhanov, K. Bashirov, S. Bystritsky, V. Hryshchenko of T. Danilov, A. Dyagilev, V. Zausayev, S. Kravchenko N. Krivoruchko, Yu. Maximova, I. Melamed, O. Mityakova, O. Moskvina, S. Mityakov, V. Sergeyev, V. Skobeeva, A. Trukhlyaeva, T. Fedoseyev, L. Filobokova, I. Shapk, I. Shevchenko, etc.

The methodological analysis of transformational and transactional factors of formation and increase in innovative capacity of the medical organizations, effectiveness of innovative policy are studied in the works by: I. Agkatseva, N. Beketov, I. Boyko, A. Bolshov, M. Gokhberg, V. Guzhov, A. Dagayev, I. Dezhina, L. Drobyshevskaya, P. Druzhinin, E. Egorov, K. Zadumkin, A. Kurilo, V. Kurchenkov, V. Kushlin, A. Makarov, V. Matveykin, S. Matviyenko, A. Moskovtsev, V. Misko, K. Mintairova, O. Nesterenko, E. Nemkovich, A. Rumyantseva, T. Fedorova, A. Tsypuk, A. Shishkina, etc.

However the listed works do not exhaust the subject. Therefore, the research and identification of conditions, opportunities, factorial restrictions, forms, methods and instruments of formation, increase and realization of innovative capacity of the medical organizations appears to be relevant.

\section{Materials, concepts and methods}

Data of official statistics of the Russian Federation and foreign countries, materials of the innovative companies, state-of-the-art and statistical reviews, publications in economic and financial journals, domestic and foreign monographic literature, Russian legislation in the field of innovative activity were used as the information base for the conducted research.

Data from Goskomstat of the Russian Federation, the Ministry of Economic Development and Trade of the Russian Federation, the Ministry of Health of the Russian Federation, information and analytical rating agency "Expert RA", selective researches and expert estimates of scientific centers were also studied within the research.

Nowadays there is no strict and common definition of "innovative potential". But having studied various experts' opinions, we can define the category "innovative potential" as the ability of any system to transformation of the actual order of things into a new state for the purpose of satisfaction of the existing or again arising requirements (subjectinnovator, consumer, market, etc.). At the same time the effective use of innovative potential does possible transition from the latent opportunity to obvious reality (namely, from a traditional state to new). Therefore, innovative potential is a kind of characteristic of ability of the system to change, improvement and progress.

Many researchers represent the structure of innovative potential as follows (fig. 1). 


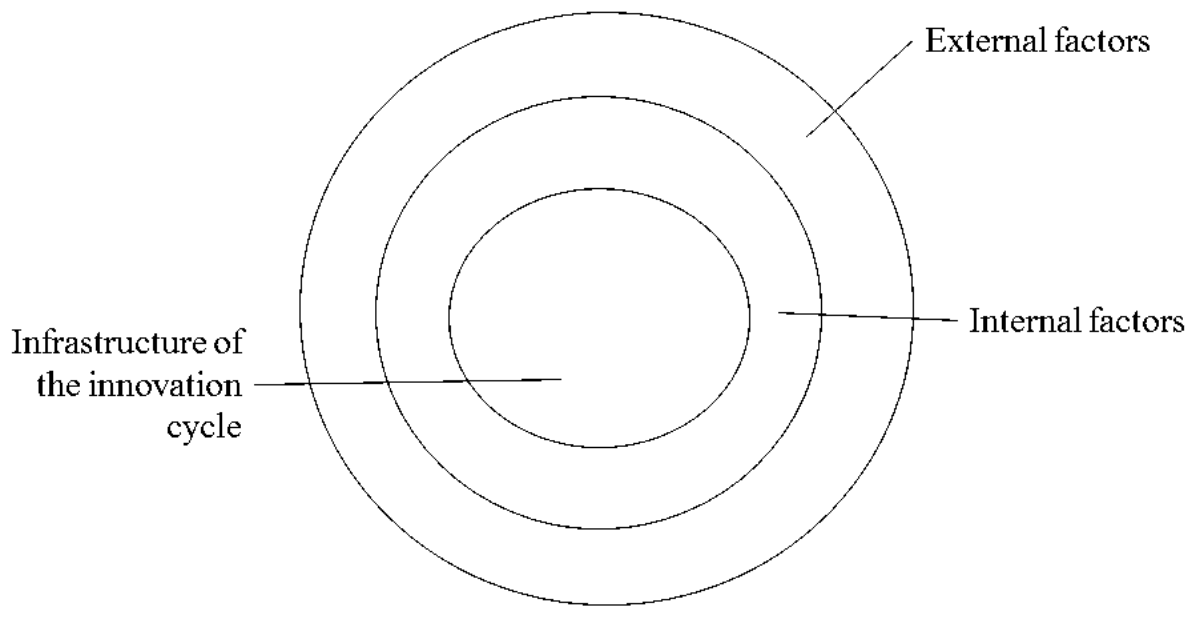

Fig. 1. Structure of innovative capacity of a medical organization.

The basis is made by innovative infrastructure of the medical organization together with innovative opportunities which are created at the expense of other potential components. Internal factors prevail over external ones and upon transition of the organization from a survival stage to a development stage significantly increase the weight.

However the above-stated determination of the structure does not realize the essence of innovative potential of the medical organization completely. The author offers another concept of the innovative capacity structure (Fig. 2).

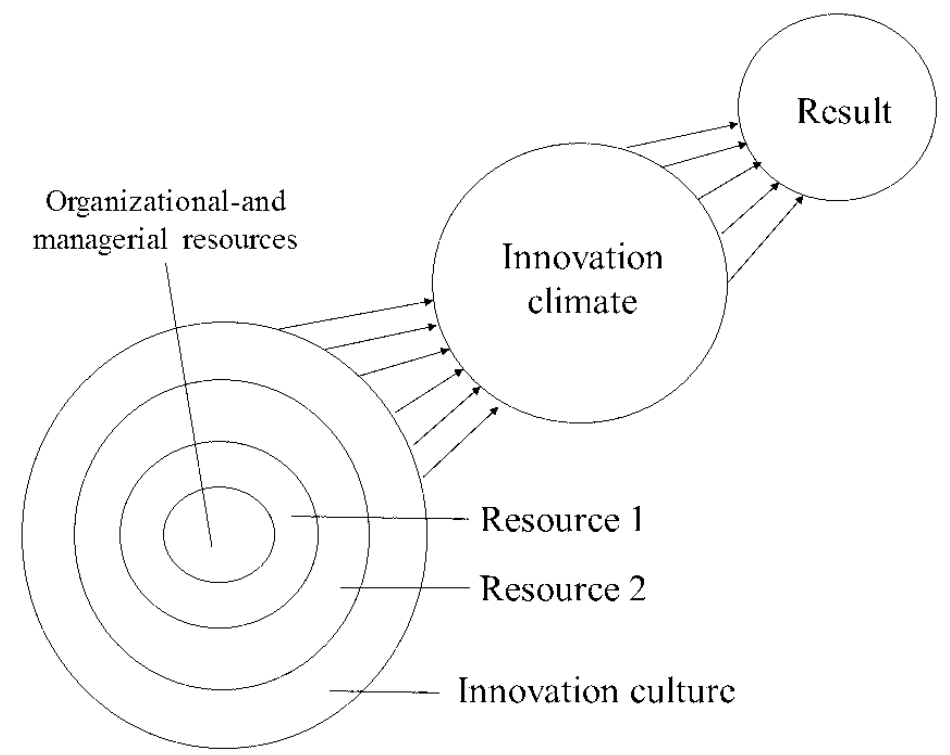

Fig. 2. Offered concept of the innovative capacity structure the innovative capacity in the medical organization.

Then, according the assumption that the innovative capacity of the medical organization represents the system of interconnected resources and opportunities of the organization, its structure can be presented in the form of hierarchical rings, each of which settles down on 
importance degree for implementation of the specific innovative project (in the drawing it is the shaded areas).

It is senseless to measure the innovative capacity of the medical organization without any assessment of ability of its implementation. Therefore it is necessary to note that the main resource is the organizational-and-administrative resource, i.e. the ability of management to mobilize and to organize the potential opportunities into the uniform system for the purpose of obtaining synergetic effect. Further other resources settle down according to the characteristic of the innovative project. The closer to the center of the structure, the more important is this component for the project realization. For example, the presence of scientists, engineers and designers will be crucial for the creation of the product, having new properties. At the same time modernization of production will require considerable financial and technical resources of the medical organization $[4,5]$.

Innovative culture is not included directly into innovative potential structure, but it is an important integral part. It is necessary to refer to innovative culture as the degree of the medical organization susceptibility to innovations innovative culture, experience of introduction of new projects, policy of management in the field of innovations, the personnel relation to innovations. Participation of innovative culture makes it possible to achieve accelerations and increases in efficiency of introduction of new technologies and inventions in the sphere of particular economy, to achieve real counteraction to bureaucratic tendencies in the management sphere, to achieve assistance to disclosure of innovative potential of the personality and its realization in education, to achieve optimization of a ratio between traditions and updating, various types and types of cultures in the sphere of culture. So, innovative potential can be presented in the form of so called "bunch" of vectors, directed to the end result. The more the capacity of the medical organization, the more probable is the positive outcome of the innovative project. But it is necessary to consider, that discovery of innovative potential encounters overcoming external barriers, such as administrative, technological, infrastructure barriers, etc.

External barriers can be characterized as innovative climate. It is necessary to refer to innovative climate as the set of the external conditions influencing the innovative capacity of the medical organization (process, technological; personnel; administrative and market innovations; possibilities of acquisition of know-how, patents; legislation, low refunding rate, preferential taxation; interaction of the power and business). Thus, barriers of innovative climate act as filters, passing through which action of vectors of innovative capacity of the medical organization significantly decreases.

Besides we studied and summarized the essence of the existing methods of development of the medical organizations innovative capacity.

Table 1. Methods of development of the medical organizations innovative capacity.

\begin{tabular}{|c|l|}
\hline Methods & \multicolumn{1}{c|}{ Description } \\
\hline \multirow{3}{*}{ Administrative } & $\begin{array}{l}\text { These methods regulate the organization activity. } \\
\text { Main ways of administrative influence: } \\
\text { • organizational influences; } \\
\text { • administrative influences; } \\
\text { • liability and collecting. }\end{array}$ \\
\hline Legal & $\begin{array}{l}\text { Development, acceptance and implementation of laws, resolutions, the } \\
\text { decrees and other normative documents, accepted by government, regulating } \\
\text { activity of the organizations of all forms of ownership. }\end{array}$ \\
\hline
\end{tabular}




\begin{tabular}{|c|l|}
\hline \multirow{5}{*}{ Economic } & $\begin{array}{l}\text { Material stimulation of the employees for the development of the } \\
\text { organization innovative capacity [6]. The methods are based on use of the } \\
\text { economic mechanism: } \\
\text { • cost accounting; } \\
\text { • compensation; } \\
\text { • market pricing; } \\
\text { • tax system; } \\
\text { • forms of ownership. }\end{array}$ \\
\hline $\begin{array}{c}\text { The ways of implementation of managerial impacts on personnel which are } \\
\text { based on the use of regularities of sociology and psychology. } \\
\text { 1. Sociological methods play an important role in management, they allow to } \\
\text { psychological }\end{array}$ \\
$\begin{array}{l}\text { establish appointment and the place of employees in the collective, to reveal } \\
\text { leaders and to provide their support, to connect motivation of people with the } \\
\text { end results of production, to provide effective communications and resolution of } \\
\text { conflicts in collective. } \\
\text { 2. Psychological methods also play very important role in the work with } \\
\text { personnel, since they are directed to the specific identity of the worker or the } \\
\text { employee and as a rule they are strictly personified and individual. }\end{array}$ \\
\hline
\end{tabular}

\section{Results}

According to the result of the research, innovative potential in the medical organizations is rather poor.

Innovative potential needs to be formed and increased purposefully, assuming the principles of existence of each particular organization, on the basis of modern approaches and methods of strategic management. That supposes a definite process (Fig. 2).

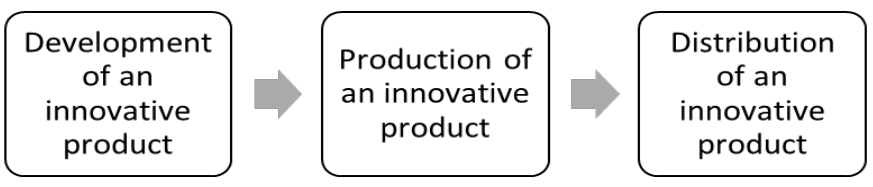

Fig. 2. Generalized process of innovative activity of the organization.

To ensure high efficiency of innovative activity of the organization, we offer development of such directions of the increase in innovative capacity of the medical organizations, which would provide not only introduction of new products, but also unconditional commercial return from such introduction $[7,6]$.

Table 2. Directions for the increase in the medical organization innovative capacity.

\begin{tabular}{|c|c|c|}
\hline General directions & $\begin{array}{c}\text { Directions of } \\
\text { measures }\end{array}$ & Measures \\
\hline & & Intra-organizational \\
$\begin{array}{c}\text { Realization of } \\
\text { organizational } \\
\text { opportunities }\end{array}$ & $\begin{array}{l}\text { 1. Improvement of corporate management; } \\
\text { 2. Improvement of organizational structure; } \\
\text { 3. Reengineering of business processes. }\end{array}$ \\
\cline { 2 - 3 } & Integration & $\begin{array}{l}\text { 1. Expansion of fields of activity according } \\
\text { to the production capabilities. }\end{array}$ \\
\hline
\end{tabular}




\begin{tabular}{|c|c|c|}
\hline \multirow{2}{*}{$\begin{array}{l}\text { Realization of } \\
\text { personnel } \\
\text { opportunities }\end{array}$} & $\begin{array}{c}\text { Scientific basis of } \\
\text { labour }\end{array}$ & $\begin{array}{l}\text { 1. Improvement of system of planning of } \\
\text { preparation of working, engineering, } \\
\text { scientific and administrative personnel and } \\
\text { also retraining of personnel }\end{array}$ \\
\hline & Stimulation & $\begin{array}{l}\text { 1. Increase in initiative of workers } \\
\text { 2. Material stimulation }\end{array}$ \\
\hline \multirow{2}{*}{$\begin{array}{l}\text { Realization of a } \\
\text { market situation at } \\
\text { the expense of } \\
\text { marketing potential }\end{array}$} & $\begin{array}{l}\text { Increase in the market } \\
\text { share }\end{array}$ & $\begin{array}{l}\text { 1. Improvement of quality of production } \\
\text { 2. Flexible price policy }\end{array}$ \\
\hline & $\begin{array}{l}\text { Increase in efficiency } \\
\text { of marketing service }\end{array}$ & $\begin{array}{l}\text { 1. Search of new marketing channels } \\
\text { 2. Deduction of old clients } \\
\text { 3. Monitoring of competitors' activity }\end{array}$ \\
\hline \multirow{2}{*}{$\begin{array}{l}\text { Realization of } \\
\text { production-and- } \\
\text { technological } \\
\text { potential }\end{array}$} & $\begin{array}{l}\text { Production } \\
\text { rearmament }\end{array}$ & $\begin{array}{l}\text { 1. Modernization } \\
\text { 2. Production diversification }\end{array}$ \\
\hline & Innovations & $\begin{array}{l}\text { 1. Support of innovative processes } \\
\text { 2. Development and implementation of } \\
\text { research and development }\end{array}$ \\
\hline \multirow{2}{*}{$\begin{array}{l}\text { Realization of } \\
\text { production-and- } \\
\text { technological } \\
\text { potential }\end{array}$} & $\begin{array}{l}\text { Interaction with the } \\
\text { government }\end{array}$ & $\begin{array}{l}\text { 1. The relations on separate types of tax and } \\
\text { collecting } \\
2 \text {. Resource providing at the expense of } \\
\text { federal and local budgets means }\end{array}$ \\
\hline & Investments & $\begin{array}{l}\text { 1. Stimulation of investors and leasing } \\
\text { companies } \\
\text { 2. Attraction of the capital for the increase } \\
\text { in innovative potential } \\
\text { 3. Issue of securities }\end{array}$ \\
\hline
\end{tabular}

We suggest, that some principles of the increase in innovative potential have to be kept for proper realization of the aforesaid directions $[9,10,11]$. These principles include:

- improvement of innovative activity for support of realization of technical policy, mission and strategy of the medical organizations;

- the integration of innovative and investment activities of the medical organizations, providing availability of resources to introduction of innovations;

- application of modern methods of planning of development of the organizations and rational combination of strategic and operational innovations in this process;

- information support of innovative activity;

- improvement of standard and methodical support of innovative activity;

- improvement of purchasing policy;

- continuous training and development of heads and personnel of the medical organizations;

- risk management, connected with innovative activity. 


\section{Discussion}

Specialists offer different approaches to the development of innovation potential. It is possible to summarize their characteristic in Table 3.

According to the author, the most effective approaches for the increase in innovative capacity of the medical organizations are process and system approaches $[12,13]$. Process and system approaches are applied as a methodical basis for creation of a quality management system today. Nowadays these approaches are considered as the approved means of improvement and the increase in the efficiency of activity of the modern organization.

Table 3. Approaches to the innovative capacity development.

\begin{tabular}{|c|l|}
\hline Approach & \multicolumn{1}{c|}{ Description } \\
\hline Personnel & $\begin{array}{l}\text { Characterizes personnel possibilities of the organization to apply } \\
\text { new knowledge and technologies, organizational and } \\
\text { administrative decisions, to execute development and to make } \\
\text { new innovative production. }\end{array}$ \\
\hline Technical-and- \\
technological & $\begin{array}{l}\text { Defines the ability to quickly reorient production capacities and to } \\
\text { arrange economically effective production of new products which } \\
\text { meet market needs. }\end{array}$ \\
\hline Information & $\begin{array}{l}\text { Displays information security of the organization, degree of } \\
\text { completeness and accuracy of information necessary for adoption } \\
\text { of effective innovative solutions. }\end{array}$ \\
\hline Financial & $\begin{array}{l}\text { Displays compliance of a financial state, investment } \\
\text { attractiveness, solvency and the system of effective management } \\
\text { of finance of the organization concerning ensuring permanent } \\
\text { innovative activity at all stages of an innovative cycle. }\end{array}$ \\
\hline Motivational & $\begin{array}{l}\text { Characterizes the possibility of the organization, concerning } \\
\text { reduction in compliance and coordination of multi-directional } \\
\text { interests of subjects of the innovative process. }\end{array}$ \\
\hline Research & $\begin{array}{l}\text { Characterizes the existence of communication communications } \\
\text { which display the level of definiteness and efficiency of } \\
\text { interaction of the organization with elements of the external } \\
\text { environment which render assistance to realization of the purpose } \\
\text { of innovative activity. }\end{array}$ \\
\hline $\begin{array}{l}\text { Displays existence of the created reserve of results of research } \\
\text { works sufficient for generation of new knowledge, ability of } \\
\text { carrying out researches for the purpose of check of the ideas of } \\
\text { innovations and a possibility of their use in production of new } \\
\text { production. }\end{array}$ \\
\hline
\end{tabular}

Process approach to the activity of the organization consists in its representation in the form of processes. Any activity or set of activities which uses resources for transformation of "entrances" to "exits" can be considered as a process [14].

System approach to management, is based on management of the system of the interconnected processes as whole and focused on the increase in effectiveness and efficiency of performance of processes as a result of minimization of inter-functional barriers. For effective increase in innovative potential in the medical organization we offer 
formation of the specialized functional direction and also subsystem of its control system directed to the development and implementation of innovative programs, achievement of the corresponding purposes and tasks, and the including functional structure, technology of activity and resources $[15,16]$.

\section{Conclusion}

According to the results of the research of the existing approaches and methods of assessment and increase in innovative capacity of the medical organizations, the most effective approaches and methods were revealed for practical application in these organizations.

When developing recommendations about the increase in innovative capacity of the medical organizations, the author referred to process and system approaches. The process and system approaches are applied as a methodical basis of creation of a quality management system of and are considered as the approved means of improvement and increase in efficiency of activity of the modern organization.

Innovative capacity of the medical organization has to include the following such components as:

1) ability of the organization to justification and development expedient (demanded by society) innovations;

2) ability of the organization to transformation of an innovation into commercial value;

3) ability of the organization to distribution of the innovative product.

For assessment of efficiency of the increase in innovative capacity of the medical organizations it is recommended to allocate the directions of obtaining efficiency, factors defining efficiency, and activity indicators which the established factors influence. The special relevance is acquired by target approach to development of an algorithm of efficiency on increase in innovative capacity of the medical organizations.

\section{References}

1. A.Trushkin, L. Demyanova, N. Malakhova, Economics and management in the health care sphere (Phoenix, Moscow, 2015)

2. A guidebook of Projekt\&Program Management For Enterprise Innovation (PMCC/ENNA, Japan, 2012)

3. E. Vasilyeva, I. Polyakova, MATEC Web of Conferences 106, 08097 (2017)

4. N. Khan, Financial model of health care sphere (Delo, Moscow, 2013)

5. A. Mottaeva, MATEC Web of Conferences 106, 08072 (2017)

6. E. Akimova, G. Potasheva, MATEC Web of Conferences 106, 08080 (2017)

7. E. Vasilyeva, A. Zlentenkov, O. Suzneva, E. Sapozhnikova, IOP (Earth and Environmental Science) 90, 12122 (2017)

8. D. Russel, Managing of High-Technology Programs and Projects (John Wileg \& Sons Inc., New York, 2012)

9. E. Vasilyeva, Economics and Entrepreneurship 6(83), 607-610 (2017)

10. T. Meshcheriakova, Economics and Entrepreneurship 10(1), 520-526 (2017)

11. T. Meshcheriakova, Applied and Fundamental Studies 2, 186-188 (2018)

12. M.A. Bahauovna, M.A. Bahauovna, International Journal of Applied Engineering Research 11(9), 6808-6816 (2016) 
13. S. Thomson et al, Financing health care in the European Union: challenges and policy responses (World Health Organization on behalf of the European Observatory on Health Systems and Policies, EU, 2009).

14. I. Polyakova, E. Chibisova, Economics and Entrepreneurship 5(70), 579-582 (2016)

15. V. Paris, M. Devaux, L. Wei, OECD Health Working Papers, 50 (2010)

16. M.A. Bahauovna, M.A. Bahauovna, International Journal of Applied Engineering Research 10(23), $43446-43449$ (2015) 